\title{
Potassium Fertilization in Soybean and Its Correlation With Electrical Conductivity in Soil
}

\author{
Maryzélia F. de Farias ${ }^{1}$, Roberto L. V. Boas ${ }^{2}$, Khalil de M. Rodrigues ${ }^{1}$, Francisca G. de S. Garreto ${ }^{1}$, \\ Marileia B. Furtado ${ }^{1}$, Luisa J. Parra-Serrano ${ }^{1}$, Francisco A. Soares ${ }^{3}$, Nítalo A. F. Machado ${ }^{4}$, \\ Analya R. F. Oliveira ${ }^{1}$, Hosana A. F. de Andrade ${ }^{4} \&$ Raissa R. S. Silva-Matos ${ }^{1}$ \\ ${ }^{1}$ Center of Agrarian Sciences and Environmental, Federal University of Maranhão, Chapadinha, Brazil \\ ${ }^{2}$ Faculty of Agronomic Sciences, State University Paulista Júlio de Mesquita Filho, Botucatu, Brazil \\ ${ }^{3}$ State Agency for Agricultural Research and Extension of Maranhão, Chapadinha, Brazil \\ ${ }^{4}$ Federal University of Ceará, Fortaleza, Brazil \\ Correspondence: Nitalo A. F. Machado, Federal University of Ceará, av. Mister Hull s/n, Pici, Fortaleza, Brazil. \\ Tel: 55-853-366-9756. E-mail: nitalo-farias@hotmail.com
}

Received: August 30, 2018

doi:10.5539/jas.v10n12p336
Accepted: September 30, $2018 \quad$ Online Published: November 15, 2018

URL: https://doi.org/10.5539/jas.v10n12p336

The research is financed by Foundation for Research and Scientific and Technological Development of Maranhão-FAPEMA.

\begin{abstract}
Soybeans stand out among the main oilseeds in the world, with potassium $\left(\mathrm{K}^{+}\right)$as the second most required nutrient and exported by the plant. The objective of this study was to evaluate the effect of potassium fertilization on soybean crop and its correlation with the electrical conductivity in a Yellow Dystrophic Latosol in the Cerrado of Maranhão. The experiments were conducted in the years of 2015 and 2016. The design was a randomized block design, with five treatments and five replications. Treatments consisted of the following $\mathrm{K}_{2} \mathrm{O}$ doses: $0,50,100,200$ and $300 \mathrm{~kg} \mathrm{ha}^{-1}$ in the sowing groove. The data collected were submitted to analysis of variance and regression. The response of soybean to potassium fertilization occurred for the mass of 100 grains. The highest grain yield was evidenced in the first year of soybean cultivation. The increase in the adjustment parameters of the regression models in the electrical conductivity of $20-40 \mathrm{~cm}$ in the second year of cultivation occurred as a function of the increase of the potassium fertilization.
\end{abstract}

Keywords: Brazilian Cerrado, Glycine max L., potassium, salinity

\section{Introduction}

Soybean cultivation is currently considered a commodity, representing one of the main products of the export (Silva et al., 2014; Dalchiavon et al., 2011). The increase in soybean agricultural productivity must be accompanied by an advance in the knowledge of the nutritional requirements of each crop, thus providing the correct use of agricultural inputs (Gonçalves Junior et al., 2010).

Soils of the Brazilian Cerrado suffer a high degree of weathering, which makes them generally deficient in potassium $\left(\mathrm{K}^{+}\right)$, so that there is no support in these areas for successive crops of soybeans due to the large amount of this nutrient extracted by the crop, requiring its return by fertilization (Serafim et al., 2012).

The cerrado areas, in the north of Brazil is characterized as soils in which the potassium reserve is not usually sufficient to supply the needs of the soybean crop. Most soybean farmers in this region use doses ranging from 100 to $200 \mathrm{~kg} \mathrm{ha}^{-1}$ of potassium chloride at sowing or cover, with no control of soil $\mathrm{K}^{+}$levels.

The prolonged use of this nutrient is an aggravating factor in the process of salinization of the soil, since the soybean farmers of the region do not use an irrigation system that could facilitate the leaching process of the salts in the soil, which may result in negative impacts to the environment, automatically reducing the sustainability of these agricultural ventures. 
The electrical conductivity has been used as an important tool in the monitoring of soil fertility characteristics, used with the objective of stratifying management zones due to its high correlation with the attributes of the soil, especially with respect to the determinant attributes of productivity, besides the low cost and agility of measurement (Alcântara et al., 2012).

Precision agriculture uses the electrical conductivity in the management of agricultural areas since it allows characterizing the variability in the field, and with this it provides a more efficient planning of the application of inputs, resulting in a greater profitability and a lower risk of soil salinity. There are problems in soybean when electrical conductivity is high in the planting groove, in which the saline environment may negatively influence the formation of bacteria of the genus Rhizobium that perform the biological nitrogen fixation process (Dalchiavon et al., 2011; Gonçalves Junior et al., 2010).

If, on the one hand, the low dose of potassium can affect the quality of the beans and the resistance of the soybean pod, on the other hand, the high dose may inhibit or decrease the inoculation and may affect the nitrogen content and consequently the productivity. Therefore, the objective of this study was to evaluate the response of soybean to potassium fertilization and its correlation with the electrical conductivity in Yellow Latosol Dystrophic, in the Cerrado of the state of Maranhão.

\section{Material and Methods}

\subsection{Characterization of the Experimental Area}

The experiments were conducted in the Experimental Area of the Center of Agrarian and Environmental Sciences of the Federal University of Maranhão, Campus IV, Chapadinha, Maranhão, Brazil, whose geographic coordinates are $03^{\circ} 44^{\prime} 28.7^{\prime \prime} \mathrm{S}$ and $43^{\circ} 18^{\prime} 46^{\prime \prime} \mathrm{W}$ and $107 \mathrm{~m}$.

The research was carried out during two years, the first experiment being carried out from January to May 2015 (Time 1), and the second experiment from September 2015 to January 2016 (Time 2). The climate of the region is classified as tropical humid (Peel et al., 2007). The rainy season is concentrated between December and July, with annual rainfall ranging from 1600 to $2000 \mathrm{~mm}$ (Nogueira et al., 2012), with an annual average temperature above $27^{\circ} \mathrm{C}$ (Passos et al., 2016).

The soil of the area was classified according to Santos et al. (2013) as Dystrophic Yellow Latosol (LAd), sandy loam texture. In the first experiment, soil samples were collected at depths of 0-20 and 20-40 cm for chemical characterization of the area and subsequent fertilization. In the second experiment, soil samples were also collected at the same depth, in each treatment to perform the chemical fertilization through the chemical analysis (Table 1).

Table 1. Chemical soil attributes of the experimental area in the first year (2015) and second year of the experiment (2016)

\begin{tabular}{|c|c|c|c|c|c|c|c|c|c|c|c|}
\hline \multicolumn{12}{|c|}{ 1st year of experiment (2015) } \\
\hline \multicolumn{2}{|c|}{ Depth of soil } & $\mathrm{pH}$ & OM & P resin & K & $\mathrm{Ca}$ & $\mathrm{Mg}$ & $\mathrm{H}+\mathrm{Al}$ & SB & CTC & $\mathrm{V}$ \\
\hline \multicolumn{2}{|c|}{-------- cm -------- } & $\mathrm{CaCl}_{2}$ & $\mathrm{~g} \mathrm{dm}^{-3}$ & $\mathrm{mg} \mathrm{dm}{ }^{-3}$ & \multicolumn{6}{|c|}{ 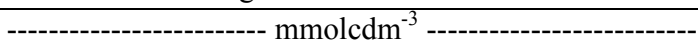 } & $\%$ \\
\hline $0-20$ & & 3.9 & 7 & 2 & 2.3 & 7 & 0 & 22 & 9.3 & 31.3 & 30 \\
\hline $20-40$ & & 4.2 & 18 & 6 & 1.5 & 7 & 5 & 25 & 13.5 & 38.5 & 35 \\
\hline \multicolumn{12}{|c|}{ 2nd year of experiment (2016) } \\
\hline $\mathrm{K}_{2} \mathrm{O}$ & DS & $\mathrm{pH}$ & MO & P resin & $\mathrm{K}$ & $\mathrm{Ca}$ & $\mathrm{Mg}$ & $\mathrm{H}+\mathrm{Al}$ & SB & CTC & V \\
\hline $\mathrm{kg} \mathrm{ha}^{-1}$ & $\mathrm{~cm}$ & $\mathrm{CaCl}_{2}$ & $\mathrm{~g} \mathrm{dm}^{-3}$ & $\mathrm{mg} \mathrm{dm}{ }^{-3}$ & \multicolumn{6}{|c|}{ - } & $\%$ \\
\hline \multirow[t]{2}{*}{0} & $0-20$ & 5.3 & 12 & 7 & 1.8 & 17 & 12 & 24 & 30.8 & 54.8 & 56 \\
\hline & $20-40$ & 4.5 & 7 & 12 & 1.7 & 4 & 13 & 24 & 18.7 & 42.7 & 44 \\
\hline \multirow[t]{2}{*}{50} & $0-20$ & 5.4 & 12 & 6 & 1.7 & 16 & 14 & 21 & 31.7 & 52.7 & 60 \\
\hline & $20-40$ & 4.4 & 5 & 5 & 1.6 & 0 & 12 & 25 & 13.6 & 38.6 & 35 \\
\hline \multirow[t]{2}{*}{100} & $0-20$ & 5.2 & 10 & 11 & 1.6 & 17 & 15 & 21 & 33.6 & 54.6 & 62 \\
\hline & $20-40$ & 4.5 & 6 & 27 & 1.5 & 2 & 12 & 25 & 15.5 & 40.5 & 38 \\
\hline \multirow[t]{2}{*}{200} & $0-20$ & 5.1 & 12 & 11 & 1.8 & 21 & 13 & 22 & 35.8 & 57.8 & 62 \\
\hline & $20-40$ & 4.4 & 8 & 43 & 2.5 & 10 & 9 & 27 & 21.5 & 48.5 & 44 \\
\hline \multirow[t]{2}{*}{300} & $0-20$ & 5.4 & 13 & 8 & 1.7 & 19 & 14 & 20 & 34.7 & 54.7 & 63 \\
\hline & $20-40$ & 4.4 & 6 & 2 & 2.2 & 6 & 6 & 25 & 14.2 & 39.2 & 36 \\
\hline
\end{tabular}

Note. OM: Organic matter; SB: Sum of bases; DS: Depth of soil. 


\subsection{Preparation and Management of the Experiment}

The preparation of the area was carried out in a conventional manner, using a plowing and sorting, with liming with $1.5 \mathrm{t} \mathrm{ha}^{-1}$ of dolomitic limestone (PRNT 68\%) in the first year of cultivation, liming in the second year. Fertilization was carried out according to the chemical characteristics of the soil and recommendations (Ribeiro et al., 1999). The irrigation system used was a sprinkler consisting of a centrifugal pump of $3 \mathrm{cv}$ and sector sprinklers with a flow rate of $0.00039 \mathrm{~m}^{3} \mathrm{~s}^{-1}$ and a radius of $10 \mathrm{~m}$. In the first year of soybean cultivation, a total leaf of $858 \mathrm{~mm}$ was applied and in the second year $920 \mathrm{~mm}$, this difference occurred due to a longer drought period in the second year of cultivation.

Planting fertilization in the first year of soybean cultivation was $50 \mathrm{~kg} \mathrm{ha}^{-1} \mathrm{~N}, 90 \mathrm{~kg} \mathrm{ha}^{-1} \mathrm{P}_{2} \mathrm{O}_{5}$ and $50 \mathrm{~kg} \mathrm{ha}^{-1} \mathrm{~K}_{2} \mathrm{O}$ in the form of ammonium sulfate, single superphosphate and potassium chloride, respectively. In the second year of cultivation, the fertilization was differentiated, with the treatment with $50 \mathrm{~kg} \mathrm{ha}^{-1}$ of $\mathrm{K}_{2} \mathrm{O}$ receiving $90 \mathrm{~kg} \mathrm{ha}^{-1}$ of $\mathrm{P}_{2} \mathrm{O}_{5}$ and $50 \mathrm{~kg} \mathrm{ha}^{-1}$ of $\mathrm{K}_{2} \mathrm{O}$, while the other treatments received $70 \mathrm{~kg} \mathrm{ha}^{-1}$ of $\mathrm{P}_{2} \mathrm{O}_{5}$ and $50.3 \mathrm{~kg} \mathrm{ha}^{-1}$ of $\mathrm{K}_{2} \mathrm{O}$ in the form of single superphosphate and potassium chloride, respectively. It was applied $86 \mathrm{~kg} \mathrm{ha}^{-1}$ of $\mathrm{N}$ in the cover, in the form of urea, in all treatments.

Each plot had a dimension of $2.5 \times 5 \mathrm{~m}$, with five rows spaced $0.50 \mathrm{~m}$ and 12 plants per linear meter. The sowing was done manually, using BRS Tracaja (Embrapa) soy-bean cultivar in the two years of cultivation, which has a medium cycle, determined growth, good resistance to bedding and dehiscence of pods with high yield potential. The seeds were previously treated with fungicide and insecticide. The seeds were also inoculated with Bradyrhizobium japonicum bacteria to facilitate $\mathrm{N}_{2}$ fixation. The dose used was $100 \mathrm{~g}$ of inoculant per $50 \mathrm{~kg}$ of seed. The thinning was performed at 15 days after emergence of the seedlings, leaving one seedling per hole. Samples of the EC and $\mathrm{K}^{+}$in the soil solution were performed every 15 days until the end of the crop cycle totaling five evaluations. Soil was harvested at the R8 stage.

\subsection{Experimental Planning, Variables and Statistical Analyzes}

The experimental design was in randomized blocks, with five treatments and five replications. The treatments were: $0,50,100,200$ and $300 \mathrm{~kg} \mathrm{ha}^{-1}$ of $\mathrm{K}_{2} \mathrm{O}$ in the sowing groove, using potassium chloride $(\mathrm{KCl})$ as the source Were evaluated: plant height, number of pods per plant, number of branches per plant, pod length, height of first pod insertion, number of grains per pod, mass of 100 grains and grain yield at $13 \%$ moisture. The electrical conductivity of the soil saturation extract (CEs) was measured at depths of 0-20 and 20-40 cm by the 2:1 method, that is, a soil part for two of water. The level of $\mathrm{K}^{+}$in the soil solution was determined with an ion meter at depths of 0-20 and 20-40 cm of soil in the year 2016 .

In the analysis of the data, normality was verified by the Kolmogorov Smirnov test and the homogeneity of variance by the Cochran Test, both at $5 \%$ significance by the ASSISTAT ${ }^{\circledR}$ program (Silva \& Azevedo, 2016). The variables were submitted to analysis of variance and Tukey's test was used in the comparison of means at $5 \%$ of probability. Regression analysis was also performed and the linear or quadratic models were chosen ac-cording to significance by the $t$ test at $5 \%$.

\section{Results and Discussion}

There was no significant effect on plant height $(F=1.974)$, height of insertion of the first pod $(F=0.991)$ and pod length $(\mathrm{F}=1.000)$ in relation to the potassium doses, how-ever, there was a difference between the times, that is, the highest values of these variables were obtained in the first year of cultivation (Table 2). This result suggests that in the first year of cultivation there was a trend towards a greater development of the crop, due to the rapid response of soybean to the application of potassium.

There was a reduction in productivity in the second year of cultivation. The lack of response of the crop to potassium fertilization in the second year of experiment is related to the residual content of $\mathrm{K}^{+}$available in the soil, $0.23 \mathrm{cmol}_{\mathrm{c}} \cdot \mathrm{dm}^{-3}$, a result of the first year of the experiment and also the absence of crop implantation interspersed, that could improve the physical-chemical characteristics of the soil between the years of soybean cultivation through the processes of decomposition and nutrient cycling.

The absence of a growing effect on soybean yield with applications above $90 \mathrm{~kg}$ ha- 1 of $\mathrm{K} 2 \mathrm{O}$ is associated with the nutritional imbalance of $\mathrm{K}^{+}$with $\mathrm{Ca}$ and $\mathrm{Mg}$ (Petter et al., 2012). Absorption of high amounts of $\mathrm{K}^{+}$may reduce the absorption or physiological availability of $\mathrm{Ca}^{2+}$ and $\mathrm{Mg}^{2+}$. Other searches did not find answer to the application of potassium doses in soybean in succession to cover plants, which indicates that the potassium fertilization did not influence in the characteristics of growth and development of the culture (Silva \& Lazarini, 2014). 
Table 2. Mean values of plant height, first pod insertion height, pod length and grain yield during the experiment period $(2015 / 2016)$

\begin{tabular}{llll}
\hline Evaluated parameter & 1 year $(2015)$ & 2 year $(2016)$ & CV $(\%)$ \\
\hline Height of plants $(\mathrm{cm})$ & $64.60 \mathrm{a}$ & $52.64 \mathrm{~b}$ & 20.34 \\
Height of insertion of the $^{\text {st }}$ pod $(\mathrm{cm})$ & $17.40 \mathrm{a}$ & $14.28 \mathrm{~b}$ & 20.34 \\
Length of the pod $(\mathrm{cm})$ & $5.0 \mathrm{a}$ & $4.56 \mathrm{~b}$ & 7.25 \\
Productivity $\left(\mathrm{Kg} \mathrm{ha}^{-1}\right)$ & $3127.60 \mathrm{a}$ & $1831.12 \mathrm{~b}$ & 47.93 \\
\hline
\end{tabular}

Note. Means followed by lowercase letters in the columns do not differ by the Tukey test at $5 \%$ probability. CV: coefficient of variation.

There was no influence of potassium doses on the number of branches per plant $(\mathrm{F}=0.383)$, number of pods per plant $(\mathrm{F}=1.441)$ and number of beans per pod $(\mathrm{F}=0.396)$, which occurred because potassium did not influence the morphological characteristics of soybean in any of the growing periods. This fact is attributed to the potassium content in the soil sufficient to meet the needs of the crop. There was a significant difference for the mass of 100 grains as a function of the doses and the times (Table 3).

The treatment without potassium application was the one that obtained the lowest value of mass during the two cultivation times being equal to the doses of 50 and $200 \mathrm{~kg}$ of $\mathrm{K}_{2} \mathrm{O}$. Time 1, that is, the first year of cultivation, had the highest mass of 100 grains. Research has already found that second crop year, the amounts of $\mathrm{K}^{+}$ absorbed by soybeans are on average much lower than in the first year, suggesting that this potassium fertilization reserve was sufficient to meet the needs of the culture in the first crops (Foloni \& Rosolem, 2008).

Table 3. Mean values for the mass of 100 grains during the experiment period.

\begin{tabular}{llll}
\hline Volume of 100 grains $(\mathrm{g})$ & & & \\
\hline Source of variation & $\mathrm{GL}$ & $\mathrm{F}$ & $\mathrm{CV}(\%)$ \\
\hline Dose & 4 & $6.369^{*}$ & 7.71 \\
Block & 4 & $4.860^{*}$ & 5.28 \\
Time & 1 & $50.658^{*}$ & 10.74 \\
Dose x Time & 4 & $0.855 \mathrm{~ns}$ & \\
\hline Dose & Volume of 100 grains $(\mathrm{g})$ & \\
\hline 0 & $14.60 \mathrm{~b}$ & \\
50 & $16.30 \mathrm{ab}$ & \\
100 & $16.80 \mathrm{a}$ & \\
200 & $16.00 \mathrm{ab}$ & \\
300 & $17.20 \mathrm{a}$ & \\
\hline Time & Volume of 100 grains $(\mathrm{g})$ & \\
\hline 1 & $17.04 \mathrm{a}$ & \\
2 & $15.32 \mathrm{~b}$ & \\
\hline
\end{tabular}

Note. $\mathrm{ns}=$ not significant, by the $\mathrm{F}$ test, $*=$ Significant at the $5 \%$ probability level by the $\mathrm{F}$ test, $* *=$ Significant at the $1 \%$ probability level by the $\mathrm{F}$ test. Means followed by lowercase letters in the columns do not differ by the Tukey test at $5 \%$ probability. Time $1=$ agricultural year (2015), Time $2=$ agricultural year (2016).

There was no significant interaction between the doses of $\mathrm{K}_{2} \mathrm{O}$ and the day after seed-ling emergence (DAE) when considering the electrical conductivity of $0-20 \mathrm{~cm}$ in the two evaluations. In the first year of the experiment the doses 0 and $50 \mathrm{~kg} \mathrm{ha}^{-1}$ of $\mathrm{K}_{2} \mathrm{O}$ presented linear effect with decreasing variation for the electrical conductivity of the soil saturation extract observed by the significance of the chosen model (Figure 1A). In the second year the doses of 0 and $100 \mathrm{~kg} \mathrm{ha}^{-1}$ of $\mathrm{K}_{2} \mathrm{O}$ presented the same decreasing trend, demonstrating that there was a reduction of CEs during the experiment (Figure 1B). This variation occurred as the soybean absorbed the soil salts faster up to the $100 \mathrm{~kg} \mathrm{ha}^{-1}$ dose of $\mathrm{K}_{2} \mathrm{O}$. The use of a dose greater than $60 \mathrm{~kg} \mathrm{ha}^{-1}$ of $\mathrm{K}_{2} \mathrm{O}$ may cause some damage to the legumes due to its saline effect, which may have occurred in this experiment with doses greater than $100 \mathrm{~kg} \mathrm{ha}^{-1} \mathrm{~K}_{2} \mathrm{O}$ (Guareschui et al., 2008). 


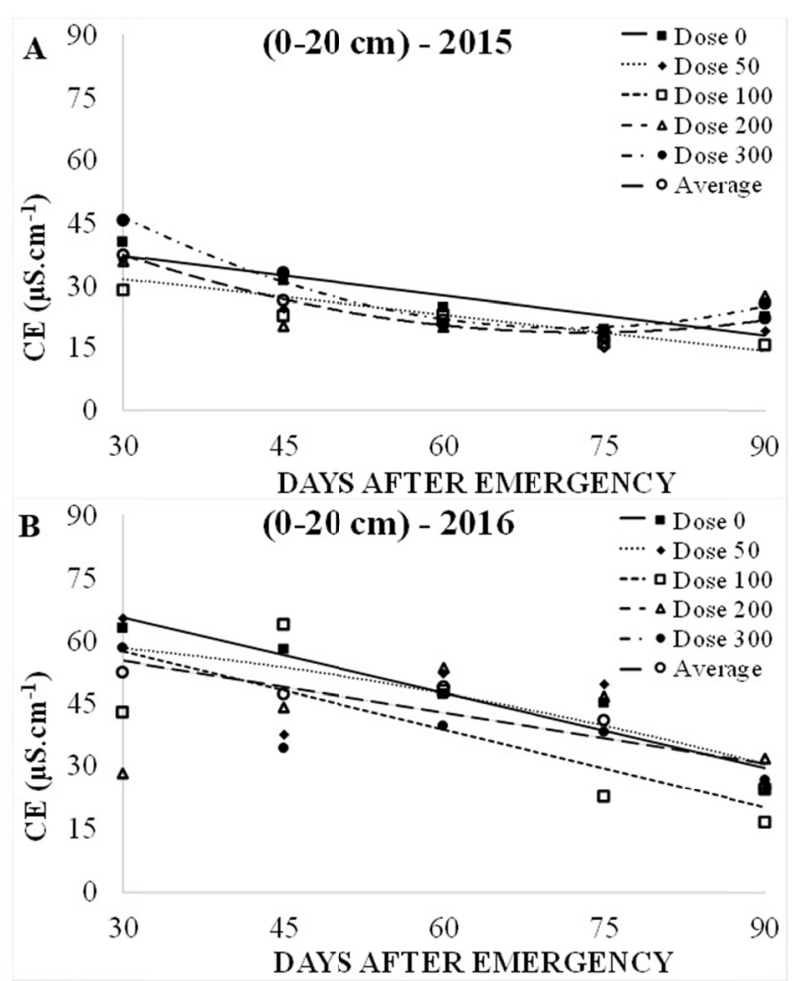

Figure 1. Variation of the electrical conductivity of the saturated soil extract in the depth of $0-20 \mathrm{~cm}$ as a function of the days after the emergency. Time $1=\left(\mathrm{A}^{1}\right)$; Time $2=\left(\mathrm{B}^{2}\right),{ }^{*}$ significant at the $5 \%$ probability level by the $t$ test

Note. ${ }^{1}$ (A) Dose $0\left(\mathrm{y}=-0.3191 \mathrm{x}+46.678 ; \mathrm{R}^{2}=0,816\right)$; Dose $50\left(\mathrm{y}=0.2886 \mathrm{x}+40.274 ; \mathrm{R}^{2}=0.7213\right)$; Dose 300 $\left(y=0.0154 x^{2}-2.2008 x+98.686 ; R^{2}=0.9821\right) ;$ Average $\left(y=0.0101 x^{2}-1.4698 x+72.418 ; R^{2}=0.9858\right)$.

${ }^{2}$ (B) Dose $0\left(\mathrm{y}=-0.5971 \mathrm{x}+83.266 ; \mathrm{R}^{2}=0.9093\right)$; Dose $50\left(\mathrm{y}=-0.0035 \mathrm{x}^{2}-0.0461 \mathrm{x}+62.62 ; \mathrm{R}^{2}=0.5182\right)$; Dose $100\left(y=-0.6197 x+75.924 ; R^{2}=0.5885\right)$; Average $\left(y=-0.4041 x+67.058 ; R^{2}=0.7879\right)$.

It can be observed in Figure 2A that the average EC values in the depth of $20-40 \mathrm{~cm}$ of the soil presented a linear effect with decreasing variation for the highest values in the doses of 200 and $300 \mathrm{~kg} \mathrm{ha}^{-1}$ of $\mathrm{K}_{2} \mathrm{O}$ in the first year of cultivation, which suggests a leaching of the salts to the higher doses of potassium applied, which can generate a residual effect of $\mathrm{K}^{+}$in the soil, damaging the culture, which is verified by the soil analysis in Time 2, that is, in the second year of cultivation, with the treatments with the highest doses of potassium leaving a higher value of residual $\mathrm{K}^{+}$in the soil. Analyzing the leaching of the potassium from potassium chloride, fine and granulated thermo-potassium, concluded that the potassium leaching was higher with the use of potassium chloride in the subsurface layers of soil, and this source presented greater mobility in the profile regardless of the type of soil (Duarte et al., 2013). 


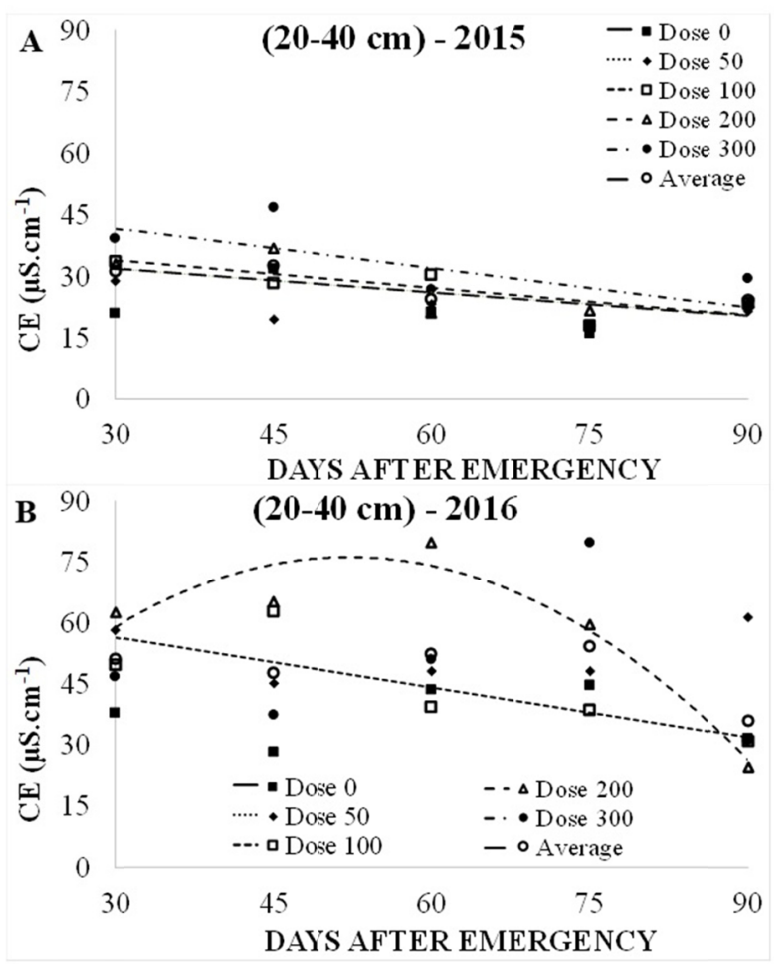

Figure 2. Variation of the electrical conductivity of the saturated soil extract in the depth of $20-40 \mathrm{~cm}$ as a function of the days after the emergency. Time $1=\mathrm{A}^{1}$; Time $2=\mathrm{B}^{2}$, ${ }^{*}$ significant at the $5 \%$ probability level by the $\mathrm{t}$ test

Note. ${ }^{1}$ A Dose $200\left(\mathrm{y}=-0.2267 \mathrm{x}+40.858 ; \mathrm{R}^{2}=0.56\right) ;$ Dose $300\left(\mathrm{y}=-0.3244 \mathrm{x}+51.492 ; \mathrm{R}^{2}=0.4736\right) ;$ Average $\left(\mathrm{y}=-0.1919 \mathrm{x}+37.638 ; \mathrm{R}^{2}=0.594\right)$.

${ }^{2} B$ Dose $100\left(Y=-0.4116 x+68.844 ; R^{2}=0.6271\right)$ Dose $200\left(y=-0.0348 x^{2}+3.6328 x-18.708 ; R^{2}=0.917\right)$.

There was a significant interaction of the electrical conductivity at depth of $20-40 \mathrm{~cm}$ as a function of time in the second year of the experiment. There was a linear effect with decreasing variation of the electrical conductivity in the soil for the treatment with $100 \mathrm{~kg} \mathrm{ha}^{-1}$ of $\mathrm{K}_{2} \mathrm{O}$, similar to that presented for the same treatment in the $0-20$ $\mathrm{cm}$ depth of the soil of the same year of the experiment (Figure 2B). The quadratic model of the regression was chosen for the dose of $200 \mathrm{~K}_{2} \mathrm{O}$. The results indicate that a change occurred in the regression model as a function of the potassium doses applied in the soil, with higher parameter of adjustments in the higher potassium fertilization. The results found by Neves et al. (2009) indicate that the increase in the electrolytic concentration of the soil solution was proportional to the increase in ion concentration in the solution, the higher the applied $\mathrm{K}^{+}$ dose the greater the residual effect.

There was no significant interaction of $\mathrm{K}_{2} \mathrm{O}$ doses with the days after seedling emergence. The linear decreasing model was significant for the dose of $300 \mathrm{~kg} \mathrm{ha}^{-1} \mathrm{~K}_{2} \mathrm{O}$ and for the average data in the first year of cultivation (Figure 3A). In the second year of cultivation, the dose of 200 and $300 \mathrm{~kg} \mathrm{ha}^{-1}$ of $\mathrm{K}_{2} \mathrm{O}$ and the mean data also presented a significant linear model, indicating that a reduction of the potassium concentration occurs as a function of the emergence time of the seedlings (Figure 3B). 


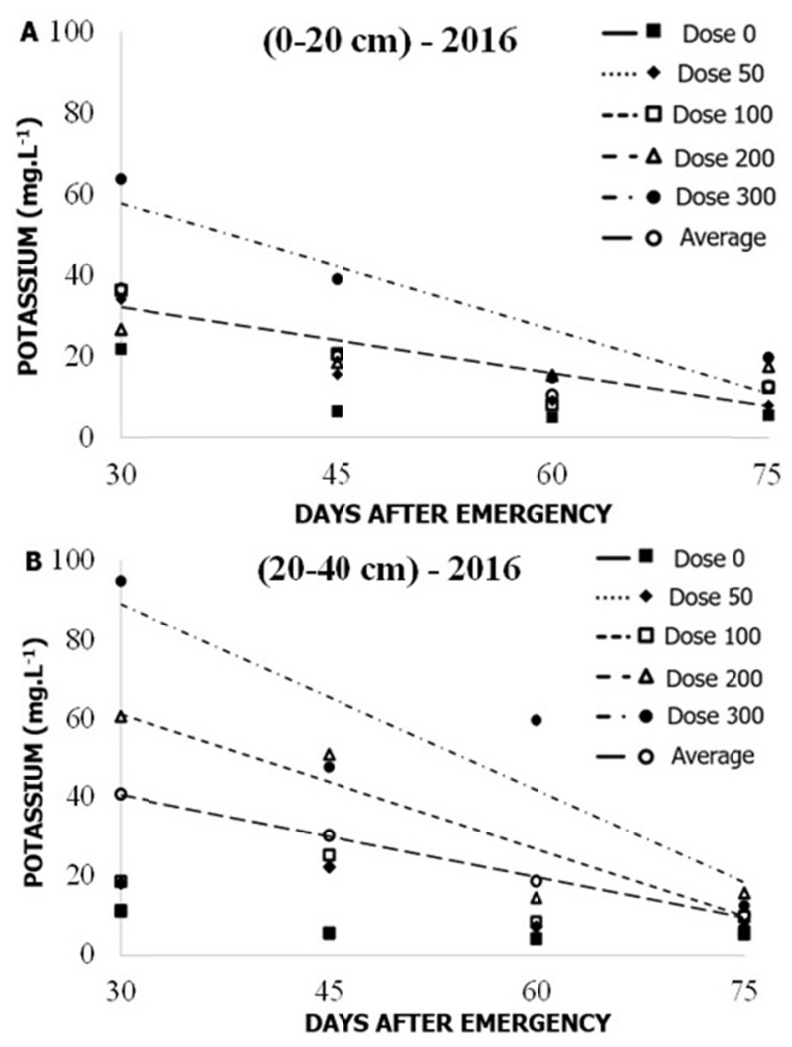

Figura 3. Variation of potassium $\left(\mathrm{mg} \mathrm{L}^{-1}\right)$ at depths evaluated in days after emergence. * at the $5 \%$ test level by the $\mathrm{t}$ test. Time $1=(\mathrm{A})$; Time $2=(\mathrm{B}),{ }^{*}$ significant at the $5 \%$ probability level by the $\mathrm{t}$ test

Note. ${ }^{1}$ A Dose $300\left(\mathrm{y}=-15.62 \mathrm{x}+73.4 ; \mathrm{R}^{2}=0.8227\right)$; Average $\left(\mathrm{y}=-8.096 \mathrm{x}+40.18 ; \mathrm{R}^{2}=0.7896\right)$.

${ }^{2}$ B Dose $200\left(y=-17.08 x+78.2 ; R^{2}=0.8605\right)$; Dose $300\left(y=-23.48 x+112.4 ; R^{2}=0.7995\right) ;$ Average $(y=$ $\left.-10.32 \mathrm{x}+50.82 ; \mathrm{R}^{2}=0.997\right)$.

It was verified that the highest dose of potassium in both years showed a linear regressive model in the regression, as well as the dose of $200 \mathrm{~kg} \mathrm{ha}^{-1}$ of $\mathrm{K}_{2} \mathrm{O}$ in the second year of cultivation due to the residual potassium value of the first year of cultivation, and may be the result of the absorption by the plant and the leaching, recorded in the soil analysis. High doses of potassium fertilizer applied for six years in the soybean crop generated a large residual effect, causing intense leaching of $\mathrm{K}^{+}$to a depth of $20 \mathrm{~cm}$ from the soil (Werle et al., 2008). Potassium salts of high solubility give the solution of the soil high levels of potassium and, considering this, this element is propitious to be leached. This occurs mainly in sandy soils due to the low CTC (Raij, 2011), which occurred during the experiment.

\section{Conclusion}

The response of the soybean to the potassium fertilization occurred for the mass of 100 grains, being that the higher grain yield was evidenced in the first year of cultivation of the crop. The increase in the adjustment parameters of the regression models in the electrical conductivity of $20-40 \mathrm{~cm}$ in the second year of cultivation occurred as a function of the increase of the potassium fertilization.

\section{References}

Alcântara, G. R., Reis, E. F., \& Queiroz, D. M. (2012). Produtividade das culturas correlacionada com condutividade elétrica aparente de um solo sob plantio direto. Revista Agrotecnologia, 3(2), 62-72. https://doi.org/10.12971/2179-5959.v03n02a06

Dalchiavon, F. C., Carvalho, M. P., Nogueira, D. C., Romano, D., Abrantes, L. F., Assis, J. T., \& Oliveira, M. S. (2011). Produtividade da soja e resistência mecânica à penetração do solo sob sistema plantio direto no cerrado brasileiro. Pesquisa Agropecuária Tropical, 41(1), 8-19. https://doi.org/10.5216/pat.v41i1.8351 
Duarte, I. N., Pereira, H. S., \& Korndörfer, G. H. (2013). Lixiviação de potássio proveniente de termopotássio. Pesquisa Agropecuária Tropical, 43(2), 195-200. https://doi.org/10.1590/S1983-40632013000200003

Foloni, J. S. S., \& Rosolem, C. A. (2008). Produtividade e acúmulo de potássio na soja em função da antecipação da adubação potássica no sistema plantio direto. Revista Brasileira de Ciência do Solo, 32(4), 1549-1561. https://doi.org/10.1590/S0100-06832008000400019

Gonçalves Junior, A. C., Nacke, H., Marengoni, N. G., Carvalho, E. A., \& Coelho, G. F. (2010). Produtividade e componentes de produção da soja adubada com diferentes doses de fósforo, potássio e zinco. Ciência e Agrotecnologia, 34(3), 660-666. https://doi.org/10.1590/S1413-70542010000300019

Guareschi, R. F., Gazolla, P. R., Souchie, E. L., \& Rocha, A. C. (2008). Adubação fosfatada e potássica na semeadura e a lanço antecipada na cultura da soja cultivada em solo de Cerrado. Semina: Agrarian Sciences, 29(4), 769-774.

Neves, L. S., Ernani, P. R., \& Simoneti, M. A. (2009). Mobilidade de potássio em solos decorrente da adição de doses de cloreto de potássio. Revista Brasileira de Ciência do Solo, 33(1), 25-32. https://doi.org/10.1590/ S0100-06832009000100003

Nogueira, V. F. B., Correia, M. F., \& Nogueira, V. S. (2012). Impacto do plantio de soja e do oceano pacífico equatorial na precipitação e temperatura na cidade de Chapadinha-MA. Revista Brasileira de Geografia Física, 5(3), 708-724. https://doi.org/10.26848/rbgf.v5i3.232870

Passos, M. L. V., Zambrzycki, G. C., \& Pereira, R. S. (2016). Water balance and climatic classification for a specific region of Chapadinha-MA. The Brazilian Journal of Irrigated Agriculture, 10(4), 758-766. https://doi.org/10.7127/rbai.v10n400402

Peel, M. C., Finlayson, B. L., \& McMahon, T. A. (2007). Updated world map of the Köppen-Geiger climate classification, Hydrol. Earth Syst. Sci., 11, 1633-1644. https://doi.org/10.5194/hess-11-1633-2007

Petter, F. A., Silva, J. A., Pacheco, L. P., Almeida, F. A., Neto, F. A., Zulfo, A. M., \& Lima, L. B. (2012). Desempenho agronômico da soja a doses e épocas de aplicação de potássio no cerrado piauense. Revista Ciências Agrárias, 55(3), 190-196. https://dx.doi.org/10.4322/rca.2012.057

Raij, B. V. (2011). Soil fertility and nutrient management. Piracicaba, SP. International Plant Nutrition Institute.

Ribeiro, A. C., Guimarães, P. T. G., \& Alvarez, V. H. (1999). Recomendação do uso de corretivos e fertilizantes em Minas Gerais: $5^{\mathrm{a}}$ aproximação (p. 359). Vicosa, MG. CFSEMG.

Santos, H. G., Jacomine, P. K. T., Anjos, L. H. C., Oliveira, V. A., Oliveira, J. B., Coelho, M. R., ... Cunha, T. J. F. (2013). Sistema Brasileiro de Classificação de Solos (3rd ed., p. 353). Brasília, DF: EMBRAPA.

Serafim, M. E., Ono, B. F., Zeviani, W. M., Novelino, J. O., \& Silva, J. V. (2012). Umidade do solo e doses de potássio na cultura da soja. Revista Ciência Agronômica, 43(2), 222-227. https://doi.org/10.1590/S180666902012000200003

Silva, F. De A. S., \& Azevedo, C. A. V. (2016). The Assistat Software Version 7.7 and its use in the analysis of experimental data. African Journal of Agricultural Research, 11(39), 3733-3740. https://doi.org10.5897/ AJAR2016.11522

Silva, A. F., \& Lazarini, E. (2014). Doses and times of application of potassium in the soy-bean crop in succession to cover crops. Semina: Agrarian Sciences, 35(1), 179-192.

Werle, R., Garcia, R. A., \& Rosolem, C. A. (2008). Lixiviação de potássio em função da textura e da disponibilidade do nutriente no solo. Revista Brasileira de Ciência do Solo, 32(6), 2297-2305. https://doi.org/10.1590/S0100-06832008000600009

\section{Copyrights}

Copyright for this article is retained by the author(s), with first publication rights granted to the journal.

This is an open-access article distributed under the terms and conditions of the Creative Commons Attribution license (http://creativecommons.org/licenses/by/4.0/). 